\title{
K-U 海綿質螺子による鎖骨骨折接合術
}

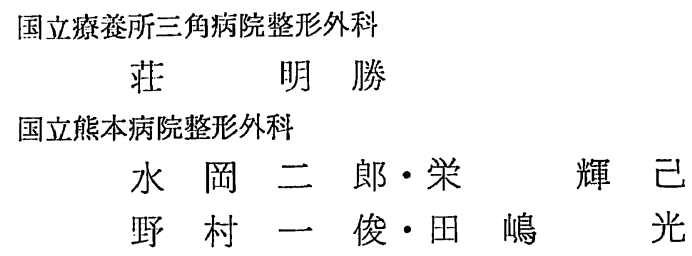

熊本県衛生部

星子
佐賀医科大学整形外科
島 田 政 博

\section{Application of K-U Cancellous Screw Compressive} Fixation for Clavicular Fracture

by

M. S. Juang

Department of Orthopaedic Surgery, National Sanatorium Misumi Hospital

J. Mizuoka, T. Sakae, K. Nomura and H. Tashima

Department of Orthopaedic Surgery, Kumamoto National Hospital

W. Hoshiko

Department of Hygiene, Kumamoto Prefecture

M. Shimada

Department of Orthopaedic Surgery, Saga Medical School

We designed $\mathrm{K}-\mathrm{U}$ cancellous screw for fixation of fracture of the clavicle. This method using $\mathrm{K}-\mathrm{U}$ cancellous screw is most suitable for fractures in the outer-middle third curvature of the bone. A type of fractures with rotation of a large intermediate fragment is also an indication for this method. We treated 21 patients during the years from 1976 to 1982 using K-U cancellous screw method. The results of this treatment were satisfactory. In one patient, the bone union was prolonged to occur about 9 months after twice repeated-operation. This prolongation was considered to be due to the damages of soft tissues, stripping ping of periosteum and blood vessels. Our method provides strong fixation for the fracture of clavicle, preventing the rotation of the bones.

はじめに

骨折の治療の原則は簡単でかつ強固な固定性を施す ことである. 星子は K-U screw による medullary fixation を考穼した．われわれは，昭和 52 年以後 6 年間に経験した K-U 海綿質螺子による観血治療法, いわゆる K-U cancellous screw compressive fixation について，その手技と問題点を報告する.
対象

本法の対象は, 定型的骨折, すなわち解剖学的外内 1/3 部の彎曲部骨折である. 第 3 片を有するすのむ対 象になる. 受傷の機転は転倒による介造外力がほとん ぞで，全症例に転位を認めた．それは銷骨の解剖学的 特徴に基因するすのである，つまり，胸鎖乳突筋の中 枢骨片への上方䇣引，肩および上肢の重量により，未 


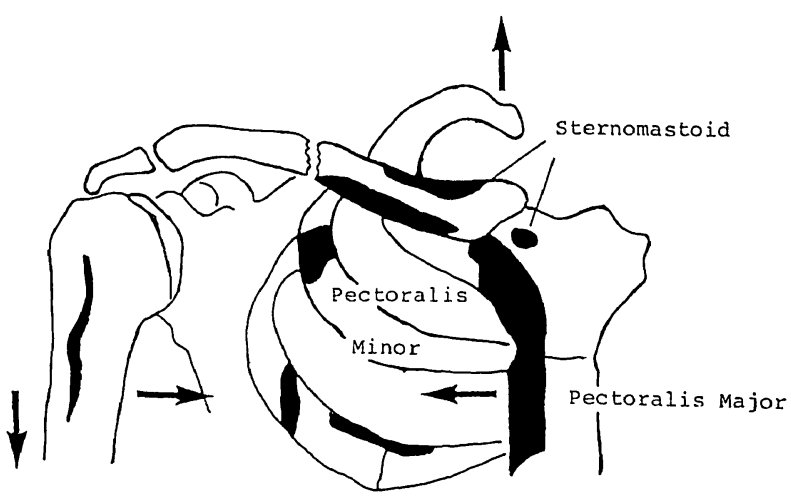

鎖骨々折転位の発生機序

図 1 銷骨骨折㕵位の発生機序（本文参胙）
A

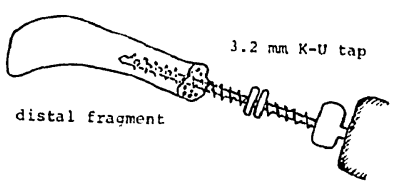

B

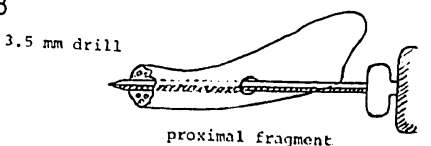

C

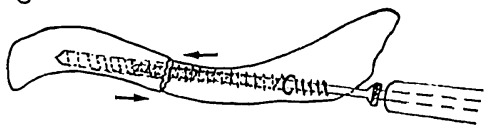

$3.2 \mathrm{~mm} \mathrm{k}$-U cancellous screw

Procedure of. Operation

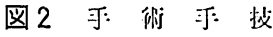

A) 桨仃の $3.2 \mathrm{~mm} \mathrm{~K}-U$ tap にて tapping

B) $3.5 \mathrm{~mm} ト$ リルにて drilling

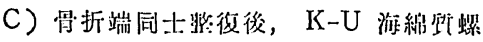
子て阔定

症例

症例 1 ：，41 才，男性。バイク走行中怪倒, 右 銧骨々折. 近医に受沴後ギプス固定，その後，K-wire で観血整復を受けた， 57 年 5 月当院初晾， レ線上 $\mathrm{K}$ wire がはずれ，第 3 骨片の回旋伝位を認めた．本法 にて再手術をおこなった. 術後 2 力月経過するも骨形 成不良，し加し，内固定良好の為，外来にて経過微 察.9力月後に骨癁合が完成した（図 3 ）。

症例 $2: \square, 68$ 才, 女性. 怪倒後左敛骨々折. 線上第 3 骨片，および転位を認めた。本法にて钼血整 復，4 力月後抜猃を施行した. ROM の障㫪はなかっ た.

症例 $3:$ 口, 56 才，女性. 忶倒後左銷骨々折, レ 線上第 3 骨片を認めた。本法にて钼血整復をおてなっ た． 3 力月後报猃．局関節の拘綟はなかった。

考察

鎖骨々折はよく谓遇する骨折のひとつで，保存的治 療でよく治瘾する，しかし，辰期間の固定により，局 関節拘縮をおこし，ADL に著しく陪㕩をきたす症例 

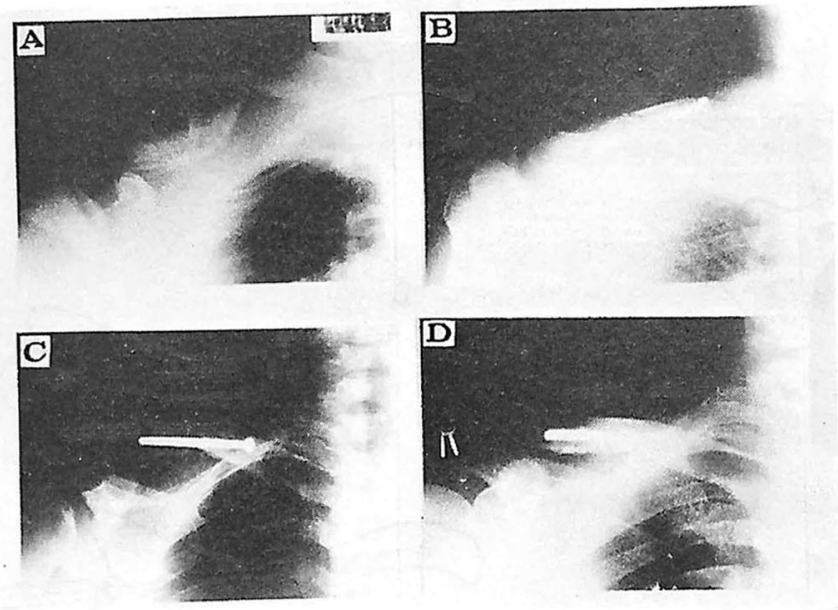

図 3
A) 受綮猔
B) 術直後
C) 術後 2 力月，骨形成やや不良
D) 術後 9 加月，骨澺合完成

$\mathrm{E}$

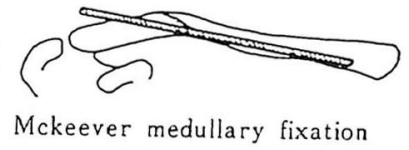

屯少なくない，観血整復の適応は，神中，S. Edomson, Neer II らが記述した如く, 転位の著しく, 第 3骨片が介在して整復障害をきたすすの，血管・神経 損傷を伴なうあの之偽関節形成の症例に限られてい た。 また Neer II の報告では, 観血整復の偽関節形 成を $3.7 \%$ 認妨机る.症例数は少ないが，われわれ の方法では nonunion の症例を認めなかった，一例 に prolonged union（図3) を認めたが，それは再 手術により㳄部組織，血管之骨膜に著しく損傷を与え た結果と考えられる。し汃し，本法の適用により，強 力な内固定が得られ，9 カ月後に 骨恣合が 完成した (図 3 ).

図 4 亿示す如く，従来の方法には，A）Kirschner wire fixation, B) Rush pin fixation, C) AO tubular plate fixation, D) Tension band wire fixation, E) McKeever medullary fixation があ る. 本法の㜆内固定という点は McKeever medullary fixation (図 4，E) と同義であるが，しかし， 本法では骨折部の圧迫固定が強力で，しか屯，海綿質 螺子の荒い山の螺旋が回旋防止にはたらいている. 皮 質蠌子よりも海綿質螺子の成績がよいのはその点にあ ると考えられる。

本法は長い斜骨折，外側あるいは内側に片上り過ぎ た鎖骨々折には適応できないのが欠点ではあるが，将

来改良を加え，適用範罒を広げたい。

$$
\text { まと め }
$$

1） K-U 海綿質螺子を用いた 鎖骨々折推血整復法 について報告した.

2）鎖骨の外中 $1 / 3$ 部彎曲部骨折が適用で，第 3 骨 片を伴うむのも刘象になる.

3）術後 Desault 包査，または三角巾固定後，㓣

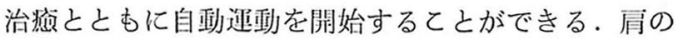
ROM 障害が認められない。

4）手術の侵警が少く，拔釷む外来で簡単にでき る.

\section{参 考 文 献}

1) Abbott, L. C. and Fonald, B. L.: The function of the clavicle. Annals of Surg., 140: 583-597, 1954.

2) Edmonson, S. et al.: Fractures. Camp. Op. Ortho., 1: 658-662, 1980.

3) 林 泰夫ほ加: K-U compression plate 使用 法の実際。整形外科と災管外科，29：13-16, 
4) Inman, V. T. and oxC, J. B., Saunders, M.: Observation of the function of the clavicle. Calif. Med. 65: 158-166, 1946.

5) Neer II, C. S.: Nonunion of the clavicle. J.A.M.A., : 172: 1006-1011, 1960.

1980.

6）神中正一：肩甲带の骨折．神中整北外科，663-
$667,1974$.

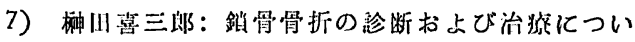
て. 整形, 形成外科部流, 1322-1323, 1981.

8) Wilson, J. N.: Fractures of the Clavicle. Watson-Jones Fracture \& J. Inj., 2: 533$538,1976$. 